\title{
An Experimental Study on Rapid Chloride Penetration Test of Self Compacting Concrete
}

\author{
Mr. R. Jeya Prakash¹ M.E., M.I.S.T.E., Ph.D., Ms. R. Nirmala² M.E., M.I.S.T.E. \\ 1,2Assistant Professor, Department of Civil Engineering, \\ ${ }^{1}$ Excel Engineering College, Komarapalayam, Tamil Nadu, India \\ 2M.V.J. College of Engineering, Bangalore, Karnataka, India
}

\begin{abstract}
How to cite this paper: Mr. R. Jeya Prakash | Ms. R. Nirmala "An Experimental Study on Rapid Chloride Penetration Test of Self Compacting Concrete" Published in International Journal of Trend in Scientific Research and Development (ijtsrd), ISSN: 24566470, Volume-3 | Issue-3, April 2019, pp.272-277, URL: http://www.ijtsrd.co $\mathrm{m} /$ papers/ijtsrd216 50.pdf

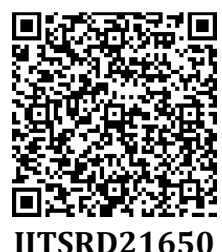

Copyright (c) 2019 by author(s) and International Journal of Trend in Scientific Research and Development Journal. This is an Open Access article distributed under the terms of the Creative Commons Attribution License (CC BY 4.0) (http://creativecommons.org/licenses/ by $/ 4.0$ )

\section{INTRODUCTION}

Concrete is the most versatile construction material because it can be designed to withstand the harshest environments while taking on the most inspirational forms. Engineers are continually pushing the limits to improve its performance with the help of innovative chemical admixtures and supplementary cementitious materials. Self-compacting concrete (SCC) is an innovative concrete that does not require vibration for placing and compaction. It is able to flow under its own weight, completely filling formwork and achieving full compaction, even in the presence of congested reinforcement. The hardened concrete is dense, homogeneous and has the same engineering properties and durability as traditional vibrated concrete.

\section{ABSTRACT}

Self-compacting concrete (SCC) is a very fluid concrete and a homogeneous mixture that solves most of the problems related to ordinary concrete. SelfCompacting Concrete gets dense and compacted due to its own self-weight. An and strength of Self-Compacting Concrete (SCC). And finally determining the hloride penetrability of SCC. Self-Compacted Concrete is generally defined as "Concrete, which does not need Compaction." Due to these characteristics, the using European method. The compressive strength, split tension test Keywords: Self compacting concrete, tensile strength, split tensile test, compressive strength, Rapid chloride penetration test placement, with faster construction times and ease of flow around congested reinforcement. The fluidity and segregation resistance of SCC ensures a high level of homogeneity, minimal concrete voids and uniform concrete strength, providing the potential for a superior level of finish and durability to the structure. The improved construction practice and performance, combined with the health and safety benefits, make SCC a very attractive solution for both precast concrete and civil engineering construction.

\section{MATERAIALS AND METHODS:}

Materials used to produce Self Compacting Concrete for the experimental investigations are, listed below with their physical properties. 
Table 1.Physical properties of self-compacting concrete materials

\begin{tabular}{|c|c|c|}
\hline Sl. No. & Particulars of Test & Observation \\
\hline \multicolumn{3}{|c|}{ Cement (OPC 53 grade) } \\
\hline 1. & Consistency & $36 \%$ \\
\hline 2. & Initial setting time & $32 \mathrm{~min}$ \\
\hline 3. & Fineness modulus & 12.33 \\
\hline 4. & Specific gravity & 3.14 \\
\hline \multicolumn{3}{|c|}{ Fine Aggregate (River sand) } \\
\hline 5. & Specific gravity & 2.60 \\
\hline 6. & Fineness modulus & 2.85 \\
\hline 7. & Water absorption & $2.5 \%$ \\
\hline 8. & Bulk density & $1690 \mathrm{~kg} / \mathrm{m}^{3}$ \\
\hline \multicolumn{3}{|c|}{ Coarse aggregate (Limited to $12 \mathrm{~mm}$ ) } \\
\hline 9. & Specific Gravity & 2.66 \\
\hline 10. & Fineness Modulus & 3.15 \\
\hline 11. & Water absorption & $1.0 \%$ \\
\hline 12. & Bulk density & $1487.6 \mathrm{~kg} / \mathrm{m} 3$ \\
\hline \multicolumn{3}{|c|}{ Fly Ash } \\
\hline 13. & Specific Gravity & 2.60 \\
\hline 14. & Fineness Modulus & 2.85 \\
\hline 15. & Water absorption & $2.5 \%$ \\
\hline \multicolumn{3}{|c|}{ Super plasticizers (Glenium B 233) } \\
\hline 16. & Chemical base & modified poly carboxylates \\
\hline 17. & Relative density & $1.08 \mathrm{~kg} / \mathrm{l}$ at $30^{\circ} \mathrm{C} \longrightarrow \mathrm{hn}$ \\
\hline 18. & Effect on setting & not retarding \\
\hline 19. & Effect of overdosing & bleeding may occur \\
\hline \multicolumn{3}{|c|}{ Viscosity Modifying Agent (VMA) } \\
\hline 20. & $\begin{array}{l}\text { Water-soluble polym } \\
\text { ability of cement pas } \\
\text { the basis for the wor } \\
\text { properties could be a }\end{array}$ & $\begin{array}{l}\text { rs that increase the viscosity of mixing water and enhance the } \\
\text { e to retain its constituents in suspension. Cement paste serves as } \\
\text { ability properties of self-compacting concrete (SCC) and these } \\
\text { sessed by self-consolidating cementitious materials (SCCM). }\end{array}$ \\
\hline
\end{tabular}

Consumption or dosage of Super Plasticizers:

For concrete of high workability, very low water/cement ration and for self-compacting concrete 1.0 to $2.0 \%$ by weight of cement used throughout the project.

MIX DESIGN AND TESTING:

Self-Compacting Concrete mix Design by European Method (M40)

The mix design of M40 grade of concrete is done by using the European method by using the test results of the materials known.

Table2. Conventional concrete mix design for M 30 grade concrete

\begin{tabular}{|c|c|c|c|c|}
\hline $\begin{array}{c}\text { Cement } \\
\mathrm{kg} / \mathrm{m}^{3} \\
(90 \%)\end{array}$ & $\begin{array}{c}\text { Fly Ash } \\
\mathrm{kg} / \mathrm{m}^{3} \\
(10 \%)\end{array}$ & Water & $\begin{array}{c}\text { FA } \\
\mathrm{kg} / \mathrm{m}^{3}\end{array}$ & $\begin{array}{c}\mathrm{CA} \\
\mathrm{kg} / \mathrm{m}^{3}\end{array}$ \\
\hline $\mathbf{4 4 7 . 0 7 3}$ & $\mathbf{3 9 . 5 5}$ & $\mathbf{1 5 8 . 2}$ & $\mathbf{9 5 5 . 1 6}$ & $\mathbf{8 3 0 . 0 6}$ \\
\hline $\mathbf{0 . 9 0}$ & $\mathbf{0 . 1 0}$ & $\mathbf{0 . 3 5}$ & $\mathbf{2 . 1 3}$ & $\mathbf{1 . 8 5}$ \\
\hline
\end{tabular}

\section{Mix proportions}

Cement (90\%)

Fly Ash (10\%)

$=447.073 \mathrm{~kg} / \mathrm{m}^{3}$

Water

$=39.55 \mathrm{~kg} / \mathrm{m}^{3}$

$=158.2$ liters $/ \mathrm{m}^{3}$

Coarse $=85.16 \mathrm{~kg} / \mathrm{m}^{3}$

VMA $(0.2 \%)=0.98 \mathrm{~kg} / \mathrm{m}^{3}$

Trail mix proportions to obtain SCC

The various trail mix proportions of different ratios are conducted in the laboratory to achieve the Self Compacting Concrete. By the addition of the super plasticizer of various ratio achieve the various Self Compacting Concrete mix. In this stage the segregation of aggregates are found. The obtained mix proportion satisfies the U-Flow test, V-Funnel test, Fill ability test and L box test. This proportion is used for further work by replacing cement with use of fly ash. After conducting number of trails we found that, the following SCC mix proportions are satisfying the required fresh properties and strength properties as per EFNARC specifications.

Table3. Proportion of Constituents of SCC

\begin{tabular}{|c|c|c|c|c|c|c|c|c|}
\hline S.No. & SCC mix & Cement & Fly ash & F.A & C.A & W/P & S.P & VMA \\
\hline 1 & SCC 1 & 0.90 & 0.10 & 2.00 & 1.74 & 1.00 & $1.00 \%$ & $1.00 \%$ \\
\hline 2 & SCC 2 & 0.90 & 0.10 & 2.00 & 1.74 & 1.00 & $1.25 \%$ & $1.00 \%$ \\
\hline 3 & SCC 3 & 0.90 & 0.10 & 2.00 & 1.74 & 1.00 & $1.50 \%$ & $1.00 \%$ \\
\hline 4 & SCC 4 & 0.90 & 0.10 & 2.00 & 1.74 & 1.00 & $1.75 \%$ & $1.00 \%$ \\
\hline 5 & SCC 5 & 0.90 & 0.10 & 2.00 & 1.74 & 1.00 & $2.00 \%$ & $1.00 \%$ \\
\hline 6 & SCC 6 & 0.90 & 0.10 & 2.00 & 1.74 & 1.00 & $2.25 \%$ & $1.00 \%$ \\
\hline 7 & SCC 7 & 0.90 & 0.10 & 2.00 & 1.74 & 1.00 & $2.50 \%$ & $1.00 \%$ \\
\hline 8 & SCC 8 & 0.90 & 0.10 & 2.00 & 1.74 & 1.00 & $2.75 \%$ & $1.00 \%$ \\
\hline
\end{tabular}




\section{Test on Fresh concrete:}

The following tests are carried out to determine the properties of fresh concrete mix. These typical requirements shown against each test method are based on current knowledge and practice.

Values outside these ranges may be acceptable if the producer can demonstrate satisfactory performance in the specific conditions, e.g., large spaces between reinforcement, layer thickness less than $500 \mathrm{~mm}$, short distance of flow from point of discharge, very few obstructions to pass in the formwork, etc. Special care should always be taken to ensure no segregation of the mix is likely as, at present, there is not a simple and reliable test that gives information about segregation resistance of SCC in all practical situations.

Table4. Acceptance Criteria for SCC

\begin{tabular}{|c|c|c|c|}
\hline $\begin{array}{l}\text { Property } \\
\text { measured }\end{array}$ & Test method & Material & Recommended values \\
\hline \multirow{3}{*}{$\begin{array}{l}\text { Flow ability } \\
\text { / Filling } \\
\text { ability }\end{array}$} & Slump flow & Concrete & $\begin{array}{l}650-800 \mathrm{~mm} \\
\text { Average flow diameter }\end{array}$ \\
\hline & $\mathrm{T}_{50}$ & Concrete & $\begin{array}{l}2-5 \mathrm{sec} \\
\text { Time to flow } 500 \mathrm{~mm}\end{array}$ \\
\hline & $V$ - funnel & Concrete / mortar & $\begin{array}{l}6-12 \text { sec } \\
\text { Time for emptying of funnel }\end{array}$ \\
\hline \multirow{2}{*}{$\begin{array}{l}\text { Passing } \\
\text { ability }\end{array}$} & $\mathrm{U}-\mathrm{box}$ & Concrete & $\begin{array}{l}0-30 \mathrm{~mm} \\
\text { Difference in heights in two limbs }\end{array}$ \\
\hline & $L-b o x$ & Concrete & $\begin{array}{l}0.8-1.0 \\
\text { Ratio of heights at beginning and end of flow }\end{array}$ \\
\hline \multirow{4}{*}{$\begin{array}{l}\text { Segregation } \\
\text { resistance }\end{array}$} & $\begin{array}{l}\mathrm{V}-\text { funnel at } \\
\mathrm{T} 5 \text { mins }\end{array}$ & Concrete & $0-3 \mathrm{~mm}$ \\
\hline & Settlement column test & Concrete cienth & $>0.95$ Segregation ratio \\
\hline & Sieve stability test & Concrete & $5-15 \%$ sample passing through $5 \mathrm{~mm}$ sieve \\
\hline & Penetration test & Concrete & Penetration depth $<8 \mathrm{~mm}$ \\
\hline
\end{tabular}

\section{Tests on hardened concrete:}

\section{Compression test:}

The cube specimen is of the size $15 \times 15 \times 15 \mathrm{~cm}$. If the largest nominal size of the aggregate does not exceed $20 \mathrm{~mm}$. Cylindrical test specimens have a length equal to twice the diameter. They are $15 \mathrm{~cm}$ in diameter and $30 \mathrm{~cm}$ long. Smaller test specimens may be used but a ratio of the diameter of the specimen to maximum size of aggregate, not less than 3 to 1 is maintained.

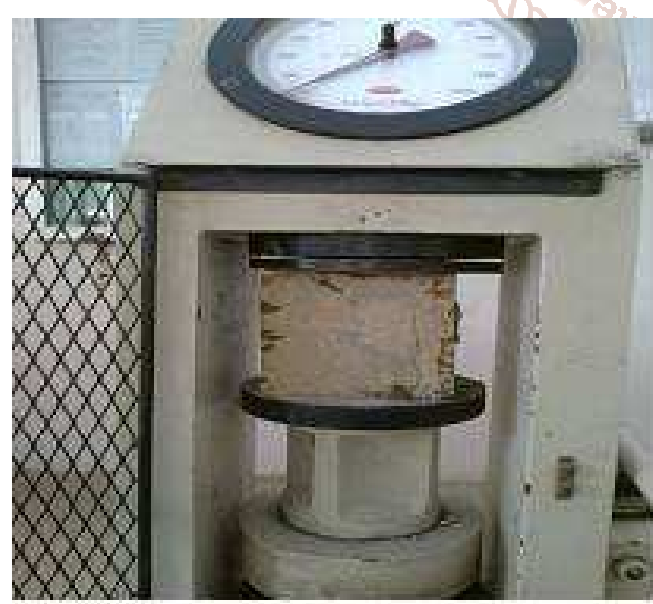

Fig1. Compression Test Setup

Compression test develops a rather more complex system of stresses. Due to compression load, the cube undergoes lateral expansion owing to the Poisson's ratio effect.

It has been found that the lateral strain in the steel plates is only 0.4 of the lateral strain in the concrete. The compression test specimens were tested on a compression testing machine of capacity $2000 \mathrm{kN}$. Load is applied gradually as the rate of $14 \mathrm{~N} / \mathrm{mm} 2 / \mathrm{min}$ or $320 \mathrm{kN} / \mathrm{min}$.
Table5. Compressive Strength of Cubes

\begin{tabular}{|c|c|c|c|c|}
\hline \multirow{2}{*}{ S.No } & Trail & \multicolumn{4}{|c|}{ Compressive Strength $\left(\mathrm{N} / \mathrm{mm}^{2}\right)$} \\
\cline { 3 - 5 } & 7 Days & 14 Days & 28 Days \\
\hline 1 & SCC 1 & 27.51 & 32.67 & 47.56 \\
\hline 2. & SCC 2 & 28.22 & 33.54 & 48.14 \\
\hline 3. & SCC 3 & 30.45 & 34.12 & 48.64 \\
\hline 4. & SCC 4 & 27.87 & 35.31 & 49.71 \\
\hline 5. & SCC 5 & 27.77 & 35.98 & 50.94 \\
\hline 6. & SCC 6 & 29.02 & 36.81 & 48.69 \\
\hline 7. & SCC 7 & 30.59 & 37.12 & 47.63 \\
\hline 8. & SCC 8 & 29.23 & 39.31 & 45.69 \\
\hline
\end{tabular}

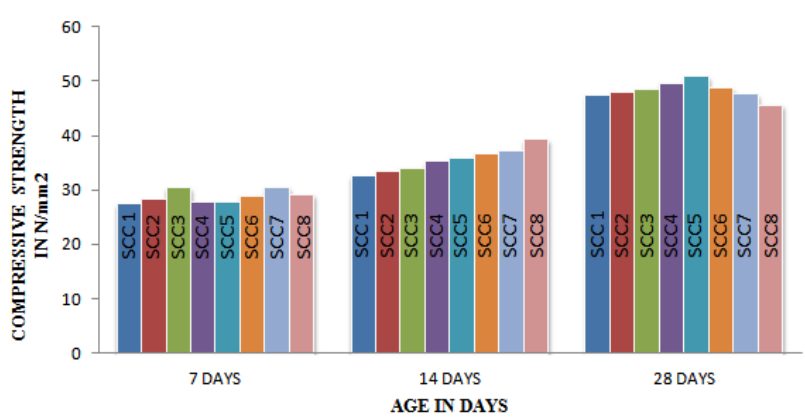

Fig2. Comparison of cube compressive strength at 7 days, 14 days and 28 days

\section{Split tensile test:}

Tensile strengths are based on the indirect splitting test on cylinders. This is also sometimes referred as, "Brazilian Test". This test was developed in Brazil in 1943. At about the same time this was also independently developed in Japan. 


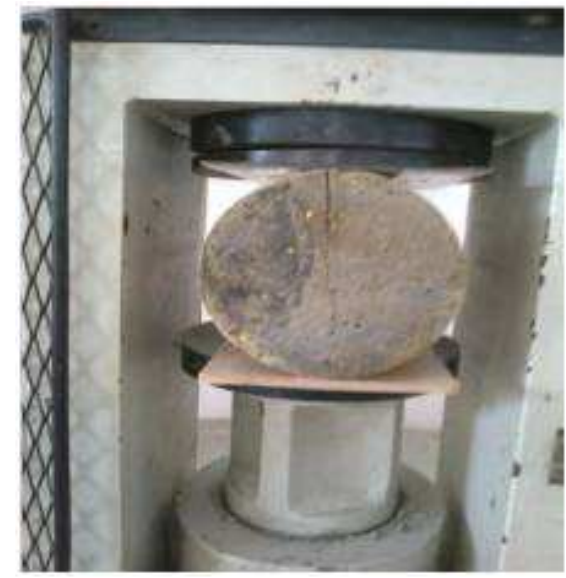

Fig3. Split Tensile Test

The test is carried out by placing a cylindrical specimen horizontally between the loading specimen of a compression testing machine and the load is applied until failure of the cylinder, along the vertical diameter. The tensile strength is one of the basic and important properties of the concrete. The concrete is not usually expected to resist, the direct tension because of its low tensile and brittle in nature. However the determination of tensile strength of concrete is necessary to determine the load at which the concrete members crack. The cracking is a form a tensile failure.

Table6. Split-Tensile strength at 7 days, 14days, 28days

\begin{tabular}{|c|c|c|c|c|}
\hline \multirow{2}{*}{ S.No } & \multirow{2}{*}{$\begin{array}{c}\text { Trail } \\
\text { Mix }\end{array}$} & \multicolumn{3}{|c|}{ Split Tensile Strength $\left(\mathrm{N} / \mathrm{mm}^{2}\right)$} \\
\cline { 3 - 5 } & 7 Days & 14 Days & 28 Days \\
\hline 1. & SCC1 & 2.80 & 3.01 & 3.92 \\
\hline 2. & SCC2 & 2.82 & 3.12 & 4.14 \\
\hline 3. & SCC 3 & 3.10 & 3.80 & 4.47 \\
\hline 4. & SCC 4 & 2.72 & 3.95 & 4.26 \\
\hline 5. & SCC 5 & 2.80 & 3.90 & 4.05 \\
\hline 6. & SCC 6 & 2.78 & 4.01 & 4.28 \\
\hline 7. & SCC 7 & 3.15 & 3.87 & 4.46 \\
\hline 8. & SCC 8 & 2.86 & 3.01 & 4.38 \\
\hline
\end{tabular}
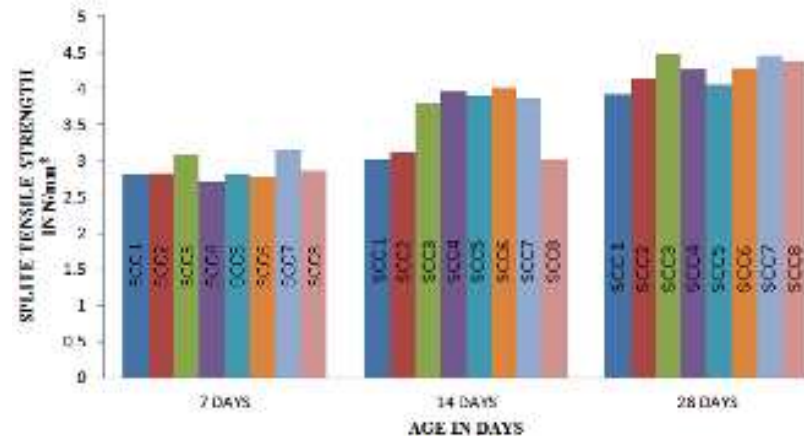

2804:

Fig4. Comparison of split tensile strength at 7days,14 days and 28days

\section{Cylinder compressive strength test:}

The cylinder are cast and tested in the same position the standard size of cylinder is $15 \mathrm{~cm}$ diameter and $30 \mathrm{~cm}$ height in actual structures in the field the casting and loading is similar to that of the cylinder and not like the cube therefore the use of cylinder is more popular particularly in the research laboratories.

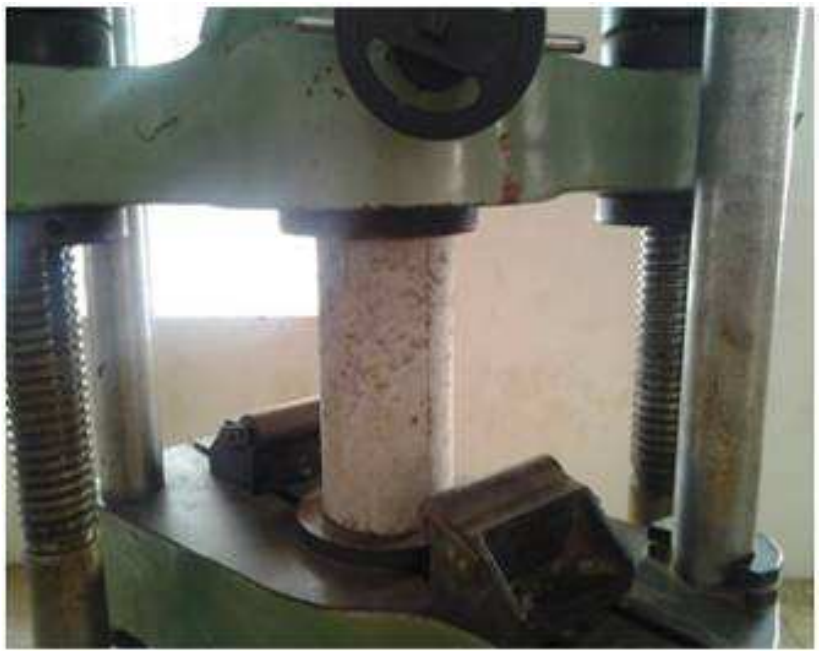

Fig.5. Cylinder compressive test

Cylinder compressive strength $=$ Ultimate load $/$ Area of cylinder

Table7. Cylinder compressive strength at 7 days, 14days, 28 days

\begin{tabular}{|c|c|c|c|c|}
\hline \multirow{2}{*}{ S. No. } & \multirow{2}{*}{ Trail } & \multicolumn{3}{|c|}{ Compressive Strength $\left(\mathrm{N} / \mathrm{mm}^{2}\right.$ ) } \\
\cline { 3 - 5 } & 7 Days & 14 Days & 28 Days \\
\hline 1 & SCC 1 & 25.50 & 26.05 & 36.75 \\
\hline 2 & SCC 2 & 24.45 & 29.88 & 38.45 \\
\hline S & SCC 3 & 28.95 & 31.33 & 39.50 \\
\hline 4 & SCC 4 & 25.88 & 27.66 & 40.25 \\
\hline 5 & SCC 5 & 30.05 & 28.98 & 41.20 \\
\hline 6 & SCC 6 & 25.45 & 33.32 & 45.28 \\
\hline 7 & SCC 7 & 27.43 & 33.43 & 45.00 \\
\hline 8 & SCC 8 & 26.56 & 28.78 & 48.75 \\
\hline
\end{tabular}

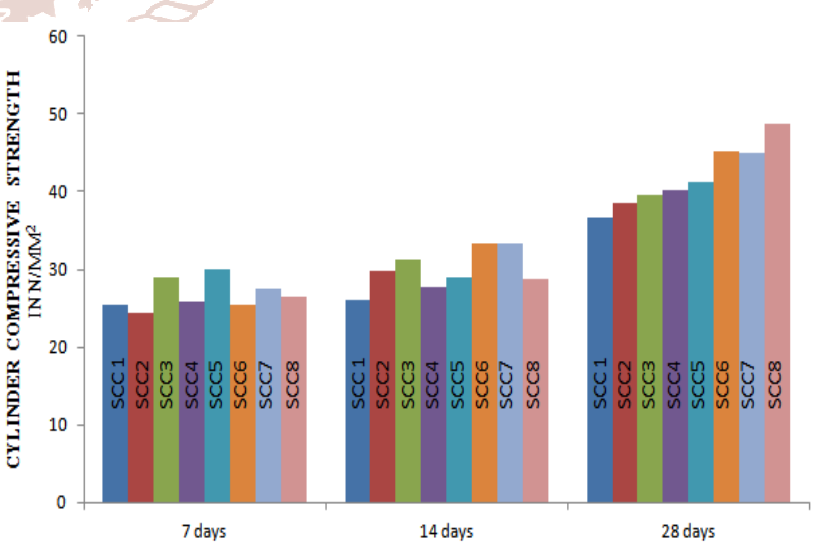

Fig6. Comparison of cylinder compressive strength at 7 days and 28 days

\section{Rapid chloride penetration test}

Accelerated chloride permeability tests were conducted on standard cylindrical specimens (100 $\mathrm{mm}$ dia, $50 \mathrm{~mm}$ thick) of self compacting Concrete. The test conducted after different periods of curing, as per ASTM C1202-1994. All the results of total charge passed through standard specimens in 6 hours (the RCPT values), taken as a measure of the chloride permeability. 
International Journal of Trend in Scientific Research and Development (IJTSRD) @ www.ijtsrd.com eISSN: 2456-6470

Table8. Rating of chloride permeability of concrete

\begin{tabular}{|l|l|l|}
\hline $\begin{array}{c}\text { Chloride } \\
\text { Permeability }\end{array}$ & $\begin{array}{c}\text { Charge } \\
\text { passing } \\
\text { Coulombs }\end{array}$ & \multicolumn{1}{|c|}{$\begin{array}{c}\text { Typical concrete } \\
\text { type }\end{array}$} \\
\hline High & $>4000$ & $\begin{array}{l}\text { High w/c ratio } \\
\text { > 0.6) } \\
\text { Conventional PC } \\
\text { concrete }\end{array}$ \\
\hline Moderate & $\begin{array}{l}2000 \text { to } \\
4000\end{array}$ & $\begin{array}{l}\text { Moderate w/c ratio } \\
\text { (0.4 to 0.5) } \\
\text { Conventional PC } \\
\text { concrete }\end{array}$ \\
\hline Low & $\begin{array}{l}1000 \text { to } \\
2000\end{array}$ & $\begin{array}{l}\text { Low w/c ratio (>0.4) } \\
\text { Conventional PC } \\
\text { concrete }\end{array}$ \\
\hline Very Low & $\begin{array}{l}100 \text { to } \\
1000\end{array}$ & $\begin{array}{l}\text { Latex-modified } \\
\text { concrete, } \\
\text { Internally sealed } \\
\text { concrete }\end{array}$ \\
\hline Negligible & $<100$ & $\begin{array}{l}\text { Polymer impregnated } \\
\text { concrete, Polymer } \\
\text { concrete }\end{array}$ \\
\hline
\end{tabular}

The diffusion cell consists of two chambers. $\mathrm{NaCl}$ solution concentration $2.4 \mathrm{M}$ and $\mathrm{NaOH}$ solution concentration $0.3 \mathrm{M}$ is prepared. $\mathrm{NaCl}$ solution concentration $2.4 \mathrm{M}$ is filled in one chamber and in another chamber $0.3 \mathrm{M} \mathrm{NaOH}$ solution is taken.

\section{Reason of conduct RCPT}

Corrosion of reinforcing steel due to chloride ingress is one of the most common environmental attacks that lead to the deterioration of concrete structures. Corrosion related damage to concrete structures is a major. This durability problem has received widespread attention in recent years because of its frequent occurrence and the associated high cost of repairs.

Chlorides penetrate crack-free concrete by a variety of mechanisms: capillary absorption, hydrostatic pressure, diffusion, and evaporative transport of these, diffusion is predominant. Diffusion occurs when the concentration of chloride on the outside of the concrete member is greater than on the inside. This results in chloride ions moving through the concrete to the level of the rebar. When this occurs in combination with wetting and drying cycles and in the presence of oxygen, conditions are right for reinforcement corrosion.

The rate of chloride ion ingress into concrete is primarily dependent on the internal pore structure. The pore structure in turn depends on other factors such as the mix design, degree of hydration, curing conditions, use of supplementary cementitious materials, and construction practices.

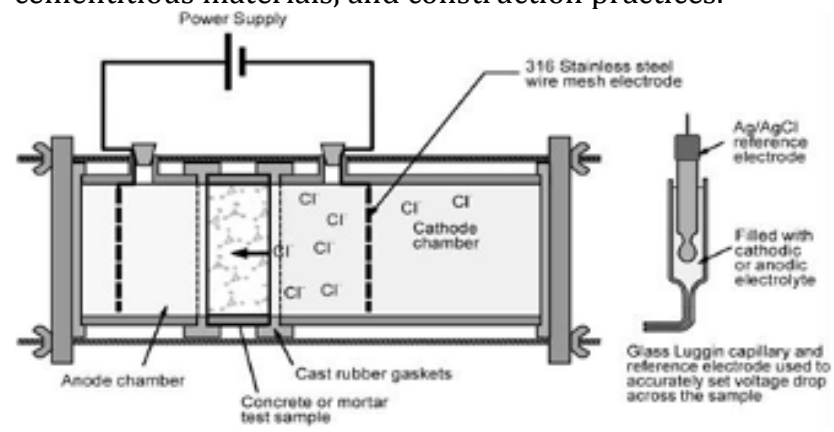

Fig. 7. Reaction of chlorine during RCPT

The chloride ions were forced to migrate through the centrally placed vacuum saturated concrete specimen under an impressed DC voltage of 60 Volts. It can also be observed that the total charge passed decreases with the increase in the curing period, measured herein up to 90 days, in specimens of all the mix compositions.

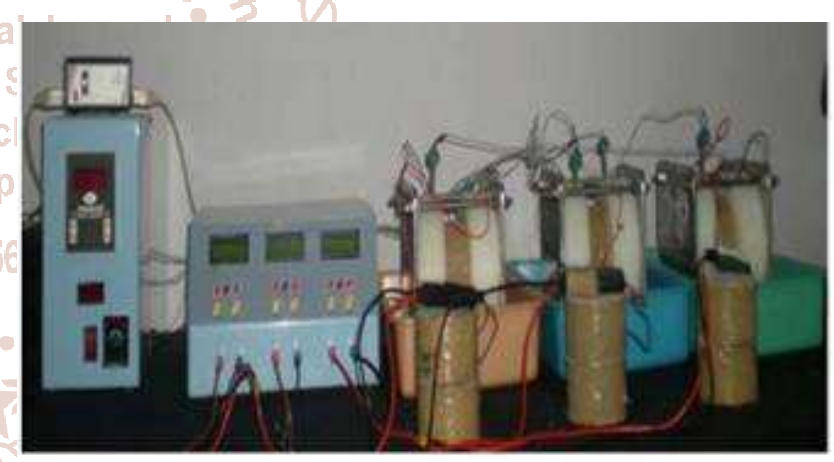

Fig.8. RCPT test apparatus

Table8. RCPT - test result

\begin{tabular}{|c|c|c|c|c|c|c|c|c|}
\hline \multirow{2}{*}{ TEST DURATION } & \multicolumn{3}{|c|}{ SCC (in mm) } & \multicolumn{3}{|c|}{$\mathrm{CC}($ in $\mathrm{mm})$} & \multirow{2}{*}{$\begin{array}{l}\text { SCC-Avg. } \\
\text { (in } \mathrm{mm} \text { ) }\end{array}$} & \multirow{2}{*}{$\begin{array}{l}\text { CC-Avg. } \\
\text { (in mm) }\end{array}$} \\
\hline & 1 & 2 & 3 & 1 & 2 & 3 & & \\
\hline & 3.4 & 3.3 & 3.4 & 3.5 & 3.9 & 3.5 & 3.36 & 3.63 \\
\hline
\end{tabular}

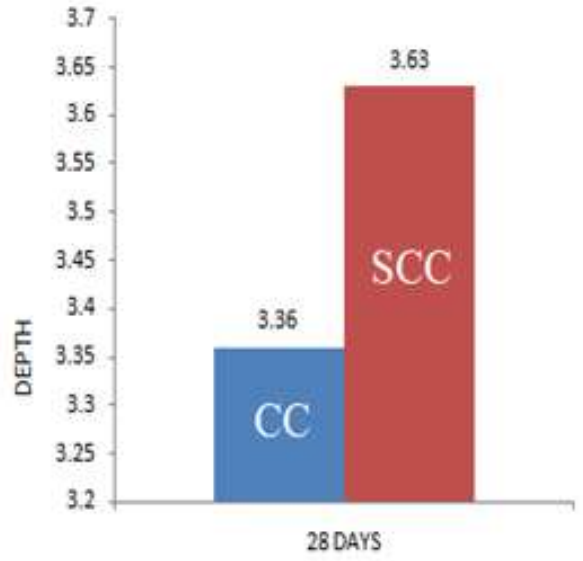

Fig.9. Graphical representation of RCPT test results

\section{ADVANTAGES:}

1. It is relatively quick- can be used for quality control

2. Has simple and convenient set up and procedures

3. Provides results that are easy to interpret

\section{DISADVANTAGES:}

1. May not repreasent the true permeability for concrete that contains supplementary cementitious material or chemical admixtures

2. May allow measurements before a steady state is achieved

3. Can cause physical and chemical changes in the specimen, result in unrealistic values

4. Has low inherent repeatability and productivity 


\section{CONCLUSION:}

The fundamental tests were conducted for all ingredients of SCC and the results were tabulated. The flow properties were checked by conducting the priliminary tests like slump flow, $\mathrm{U}$ box, $\mathrm{V}$ funnel, $\mathrm{L}$ box tests. The mix SCC5 gives the optimum results of filling ability, passing ability and segregation resistance. It also gives the optimum cube compression strength, split tensile strength, chloride resistance strength.

From these results, it was observed $1 \%$ of super plasticizer and $0.4 \%$ of viscosity modifying admixtures give better fresh and mechanical properties of SCC. The optimum dosage of super plasticizer was found to be $2 \%$ and viscosity modifying agent was found to be $1 \%$ by weight of binder. From the experimental investigation, it was observed that the SCC mix satisfied the acceptance criteria of fresh property and mechanical property. From the test result, SCC has high resistance power to the permeability of chloride than conventional concrete.

\section{REFERENCES:}

[1] Alonso. M. C, Sanchez. M, Rodriguez. C, Barragan.B (2008) 'Durability Of Scc Reinforced With Polymeric Fibers: Interaction With Enviroment And Behaviour Against High Temperatures', pp.227-235.

[2] Amrutha, Gopinatha Nayak, Mattur C. Narasimhan and S.V.Rajeeva(2011) 'Chloride-Ion Impermeability of Self-Compacting High-Volume Fly Ash Concrete Mixes', Vol: 11 No: 04, pp.29-35.

[3] Brouwers.H.J.H, Radix.H.J (2005), 'Self-Compacting Concrete: Theoretical and experimental study', Cement and Concrete Research 35, pp.2116- 2136.

[4] Dubey Sanjay Kumar and Chandak Rajeev (2012), 'Development of Self Compacting Concrete by use of Portland Pozzolana Cement, Hydrated Lime and Silica Fume', ISCA Journal of Engineering Sciences, Vol. 1(1), pp.35-39.

[5] Franco Mola, Politecnico di Milano (2004), 'The Chemical, Physical, Mechanical Properties Of Scc', A Wide Research Programme In Progress In Italy, 29th
Conference on Our World In Concrete \& Structures, pp.69-80.

[6] Gaywala.N R, Raijiwala.D B,(2011)'Self Compacting Concrete: A Concrete Of Next Decade', Journal of Engineering Research and Studies,Vol:II,pp.213-218.

[7] George Quercia, Przemek Spiesz, Götz Hüsken and Jos Brouwers (2012), 'Effects Of Amorphous Nano-Silica Additions On Mechanical And Durability Performance Of Scc Mixtures'.

[8] Gísli Guðmundsson, 'Durability of High Strength SelfCompacting Concrete' (HSSCC) - A study based on laboratory tests and field performance, pp.1-18.

[9] Mayur B. Vanjare, Shriram H. Mahure (2012), 'Experimental Investigation on Self Compacting Concrete Using Glass Powder', Vol. 2, Issue 3, pp.14881492.

[10] Md Nor Atan, Hanizam Awang(2011), 'The Compressive And Flexural Strengths Of SelfCompacting Concrete Using Raw Rice Husk Ash', Journal of Engineering Science and Technology,Vol. 6, No. 6- pp.720 - 732.

[11] Paratibha Aggarwal1, Rafat Siddique2, Yogesh Aggarwal1, Surinder M Gupta1 (2008), 'SelfCompacting Concrete - Procedure for Mix Design', leonardo electronic journal of practices and technologies issn 1583-1078 issue 12, pp.15-24.

[12] Pereira De Oliveira1.L. A, Castro Gomes.J.P, Gonilho Pereira.C.N (1999), 'Study of Sorptivity of SelfCompacting Concrete with Mineral Additions'.

[13] Safiuddin. Md, West. J.S, and Soudki. K.A (2008), 'Durability Performance of Self-Consolidating Concrete', Journal of Applied Sciences Research, 4(12):pp.1834-1840.

[14] Shahul Hameed. V, Sekar. A. S. S, Saraswathi. V, 'Chloride Penetration Study on Self-Compacting Green Concrete Using Crusher Rock Dust and Marble Sludge Powder as Fine Aggregate'. 